\title{
The Effect of Self-Esteem and Family Environment on the Dimensions of Spiritual Intelligence of the Pre-Service Teachers at the Secondary Stage
}

\author{
Keerti Vibha \\ Lovely professional university \\ Mailing address: \# 3190/1, sector 44D, chandigarh \\ Tel. 9417440630,8146311554 \\ E-mail: vibha.keerti@gmail.com
}

\begin{abstract}
The objectives of the study were to study the differences between Low \& High SelfEsteem and Non Congenial \& Congenial Family Environment groups of Pre Service Teachers at the Secondary Stage on the dimensions of Spiritual Intelligence, and to study the double interaction effects of the variables of Self-Esteem and Family Environment on the dimensions of Spiritual Intelligence in respect of the Pre Service Teachers at the Secondary Stage. The results of ANOVA showed that Low and High Self-Esteem groups exhibited no significant differences on the variables of Transcendence, Interconnectedness, Expansion of Self, Extrasensory Perception and Existential Enquiry. In case of Family Environment groups- Non Congenial and Congenial, the differences were found significant on the variables of Transcendence and Interconnectedness in favour of Congenial Family Environment and no significant differences were found on the variables of Expansion of Self, Extrasensory Perception and Existential Enquiry. The double interaction effects of the variables of Self-Esteem and Family Environment were not significant on all the dimensions of Spiritual Intelligence.
\end{abstract}

Keywords: Spiritual Intelligence, Self-Esteem, Family Environment and Pre Service teachers.

\section{INTRODUCTION}

\section{Self-Esteem}

The most broad and frequently used definition of Self-Esteem in psychology is Rosenberg's (1965), who described it as a favourable or unfavourable attitude towards the self. Self-Esteem is an extremely popular construct within psychology, and this has been related to virtually every other psychological concept or domain, including personality (e.g. shyness), behavioral (e.g. task performance), cognitive (e.g. attribution bias), and clinical concepts (e.g. anxiety and depression).

It refers to an individual's sense of his or her value or worth, or the extent to which a person values, approves of, appreciates, prizes or likes him or herself (Blascovich \& Tomaka, 1991).

Issues and Ideas in Education Vol. 1, No. 1 March 2013 pp. $51-58$ ChIMARA 司

C 2013 by Chitkara University. All Rights Reserved. 
Family Environment refer to the kind of conditions which prevail in family and which influence the all round development of the individual which works as a basis for whole life. It includes all sorts of moral and ethical values and emotional, social and intellectual climate set up by family members to contribute to the wholesome development.

Family Environment is a complex of social and cultural, conditions, the combinations of extrinsic physical conditions that effect and influence the growth and development of members of family, the most instinctive fundamental social unit which includes parents and children.

Freud (1953), from psycho-analytical point of view, stated that parent child interaction is of great importance. According to him child's self concept and adjustment depends chiefly upon the ways his instructional needs are met by the parents.

\section{SPIRITUAL INTELLIGENCE}

Spiritual Intelligence is the human capacity to ask ultimate questions about the meaning of life and to experience simultaneously the seamless connection between each of us and the world in which we live. According to Sisk and Torrance (2001), Spiritual Intelligence is the ability to use a multi- sensory approach to problem solving and to learn to listen to your inner voice. According to Wolman (2003), each of us possesses Spiritual Intelligence and we have the capacity to think with our souls. Spiritual Intelligence can be defined against or observed through some criteria, such as truthfulness, compassion, respect for all, levels of consciousness, constructive empathy, a sense of being a player in a large generosity of spirit and action, a seeking of being 'in tune' with or 'in synch' with the universe, and being comfortable with being alone without being lonely . Spiritual Intelligence can make us more spiritually intelligent about religion and can put in touch with the meaning and essential spirit behind all great religions.

The present study was conceived in the context of the non- availability of the studies pertaining to the effect of the variables of Self-Esteem and Family Environment on Spiritual Intelligence and its dimensions in northern region in general and Lovely Professional University, Phagwara in particular.

\section{OBJECTIVES}

The present study has been conducted keeping in mind the following objectives: 
1. To study the differences between Low and High Self-Esteem groups of Pre Service Teachers at the Secondary Stage on the dimensions of Spiritual Intelligence given below:
(a) Transcendence
(b) Interconnectedness
(c) Expansion of self
(d) Extrasensory Perception
(e) Existential Inquiry

2. To work out the differences between Non Congenial and Congenial Family Environment groups of Pre Service Teachers at the Secondary Stage on the dimensions of Spiritual Intelligence given below:
(a) Transcendence
(b) Interconnectedness
(c) Expansion of self
(d) Extrasensory perception
(e) Existential Inquiry

3. To study the double interaction effects of the variables of Self-Esteem and Family Environment on the dimensions of Spiritual Intelligence in respect of the Pre Service Teachers at the Secondary Stage.

\section{Hypotheses}

The following hypotheses were formulated for the conduct of the present study:

1. There exist no significant differences in the mean scores of Low and High groups of Self-Esteem of Pre Service Teachers at the Secondary Stage on the dimensions of Spiritual Intelligence.

2. There exist no significant differences in the mean scores of Non-Congenial and Congenial Family Environment groups of Pre Service Teachers at the Secondary Stage on the dimensions of Spiritual Intelligence.

3. There exist no significant two way interaction effects between Self-Esteem and Family Environment on the dimensions of Spiritual Intelligence of Pre Service Teachers at Secondary Stage.

\section{METHOD}

'Descriptive Survey Method of Research' was adopted to conduct the present study. 
In this study $2 \times 2$ factorial design was used as the purpose of the study was to examine the effects of Self-Esteem and Family Environment on the dimensions of Spiritual Intelligence of Pre-service teachers at the Secondary Stage. In the present study, the independent variables were Self-Esteem and Family Environment whereas dimensions of Spiritual Intelligence as given by Sharma and Khurana were the dependent variables.

Each of the Independent variables was studied at two levels. The two levels of Self-Esteem were Low Self-Esteem group and High Self-Esteem group, the levels of Family Environment were Non Congenial Family Environment and Congenial Family Environment.

\section{SAMPLE}

In the present study the population consisted of 500 Pre Service Teachers at Secondary level from the School of Education, Lovely Professional University, Phagwara. The entire population was taken up for the study. Thus the sample in the present context stands for the entire population of the B.Ed. students of School of Education, Lovely Professional University, Phagwara. Out of the population of 500 students, multistage sampling was done as detailed below:

The tool of Self-Esteem was administered to the Pre Service Teachers and Low and High groups of Self-Esteem were formed in accordance to the requirements of Kelley's (1939) criterion by taking Bottom 27\% and Top 27\% students representing the Low and High Self-Esteem groups respectively.

In the second stage, the Family Environment Scale was administered and two further groups out of the earlier groups (Low and High Self-Esteem) based on Family Environment were formulated. This further grouping was also based on Kelley's (1939) consideration of taking top and bottom $27 \%$ teacher trainees as forming Non Congenial and Congenial Family Environment groups.

Thus, in all 4 treatment groups were formed as per requirement of the $2 \times 2$ factorial design.

\section{STATISTICAL TECHNIQUES USED}

1. Descriptive statistical measures like mean and standard deviation were used in order to describe the nature of the sample taken.

2. Inferential statistics like one way and two way ANOVA were employed for the purpose of inferential analysis. 


\section{TOOLS}

The investigator used the tools of Spiritual Intelligence Scale developed by Sharma and Khurana (2010), Self-Esteem Inventory by Stanley Coopersmith (1975) and Family Environment Scale developed by Bhatia and Chadha (1993) for the data collection.
Dimensions

of Spiritual Intelligence of the Pre-Service

Teachers at the Secondary Stage

\section{ANALYSIS AND INTERPRETATION OF RESULT}

Table 1: Mean and S.D. of Various groups

\begin{tabular}{|l|c|c|c|c|c|c|c|c|}
\hline \multirow{2}{*}{} & \multicolumn{4}{|c|}{ Self-Esteem } & \multicolumn{4}{c|}{ Family Environment } \\
\cline { 2 - 9 } & \multicolumn{2}{|c}{ Low } & \multicolumn{2}{c|}{ High } & \multicolumn{2}{c|}{ Non Congenial } & \multicolumn{2}{c|}{ Congenial } \\
\cline { 2 - 9 } & Mean & S.D. & Mean & S.D. & Mean & S.D. & Mean & S.D. \\
\hline Transcendence & 42.63 & 6.103 & 44.88 & 5.919 & 42.10 & 6.804 & 45.90 & 5.021 \\
\hline Interconnectedness & 36.33 & 7.732 & 38.88 & 6.255 & 35.85 & 5.548 & 40.36 & 7.581 \\
\hline Expansion of Self & 74.54 & 11.580 & 77.61 & 13.555 & 76.40 & 9.540 & 78.83 & 14.37 \\
\hline $\begin{array}{l}\text { Extrasensory } \\
\text { Perception }\end{array}$ & 26.27 & 5.215 & 26.99 & 3.670 & 26.49 & 6.794 & 27.61 & 3.976 \\
\hline Existential Enquiry & 33.57 & 5.418 & 34.39 & 3.894 & 33.84 & 4.827 & 34.41 & 4.795 \\
\hline
\end{tabular}

Table 2: Summary Table of ANOVA for Main and Interaction Effects of Variables of Self-Esteem and Family Environment on the Dimension of Transcendence

\begin{tabular}{|l|r|r|r|r|c|}
\hline Source & $\begin{array}{l}\text { Type III Sum } \\
\text { of Squares }\end{array}$ & Df & $\begin{array}{l}\text { Mean } \\
\text { Squares }\end{array}$ & \multicolumn{1}{c|}{ F } & $\begin{array}{l}\text { Level of } \\
\text { Significance }\end{array}$ \\
\hline Self Esteem & 57.507 & 1 & 57.507 & 1.532 & Not Significant \\
\hline Family Environment & 451.563 & 1 & 451.563 & 12.030 & .01 \\
\hline $\begin{array}{l}\text { Self-Esteem * Family } \\
\text { Environment }\end{array}$ & .340 & 1 & .340 & .009 & Not Significant \\
\hline Error & 5255.250 & 140 & 37.538 & & \\
\hline
\end{tabular}

This above table reveals that the $\mathrm{F}$ ratio of main effect of Self-Esteem on Transcendence is not significant and Fratio of main effect of Family Environment on Transcendence is significant at .01 level and in favour of Congenial Family Environment group. There is no significant interaction effect of Self-Esteem and Family Environment on the dimension of Transcendence. 
Vibha, K.

56

Table 3: Summary Table of ANOVA for Main and Interaction Effects of Variables of Self-Esteem and Family Environment on the Dimension of Interconnectedness

\begin{tabular}{|l|r|r|r|r|c|}
\hline Source & \multicolumn{1}{|c|}{$\begin{array}{c}\text { Type III Sum } \\
\text { of Squares }\end{array}$} & \multicolumn{1}{c|}{ Df } & \multicolumn{1}{c|}{$\begin{array}{c}\text { Mean } \\
\text { Squares }\end{array}$} & \multicolumn{1}{c|}{ F } & \multicolumn{1}{c|}{$\begin{array}{c}\text { Level of } \\
\text { Significance }\end{array}$} \\
\hline Self Esteem & 175.563 & 1 & 175.563 & 2.881 & Not Significant \\
\hline $\begin{array}{l}\text { Family } \\
\text { Environment }\end{array}$ & 1116.674 & 1 & 1116.674 & 18.328 & .01 \\
\hline $\begin{array}{l}\text { Self-Esteem } \\
\text { * Family } \\
\text { Environment }\end{array}$ & .063 & 1 & .063 & .001 & Not Significant \\
\hline Error & 8529.861 & 140 & 60.928 & & \\
\hline
\end{tabular}

Above table shows that the main effect of Self-Esteem on Interconnectedness is not significant. The main effect of Family Environment is significant at .01 level and in favour of Congenial Family Environment group. And there is no significant interaction effect of Self-Esteem and Family Environment on the dimension of Interconnectedness.

Table 4: Summary Table of ANOVA for Main and Interaction Effect of Variables of Self-Esteem and Family Environment on the Dimension of Expansion of Self

\begin{tabular}{|l|r|r|r|r|l|}
\hline Source & $\begin{array}{l}\text { Type III Sum } \\
\text { of Squares }\end{array}$ & Df & $\begin{array}{l}\text { Mean } \\
\text { Squares }\end{array}$ & F & $\begin{array}{l}\text { Level of } \\
\text { Significance }\end{array}$ \\
\hline Self Esteem & 13.444 & 1 & 13.444 & .062 & Not Significant \\
\hline $\begin{array}{l}\text { Family } \\
\text { Environment }\end{array}$ & .111 & 1 & .111 & .001 & Not Significant \\
\hline $\begin{array}{l}\text { Self-Esteem } \\
\text { * Family } \\
\text { Environment }\end{array}$ & 491.361 & 1 & 491.361 & 2.279 & Not Significant \\
\hline Error & 30179.056 & 140 & 215.565 & & \\
\hline
\end{tabular}

The above table depicts that the main effects of the variables of Self-Esteem and Family Environment on Expansion of Self is not significant. And there is no significant interaction effect of Self-Esteem and Family Environment on the dimension of Expansion of Self. 
Table 5: Summary Table of ANOVA for Main and Interaction Effects of Variables of Self-Esteem and Family Environment on the Dimension of Extrasensory Perception

\begin{tabular}{|l|r|r|l|l|l|}
\hline Source & $\begin{array}{l}\text { Type III Sum } \\
\text { of Squares }\end{array}$ & Df & $\begin{array}{l}\text { Mean } \\
\text { Squares }\end{array}$ & F & $\begin{array}{l}\text { Level of } \\
\text { Significance }\end{array}$ \\
\hline Self Esteem & 29.340 & 1 & 29.340 & 1.282 & Not Significant \\
\hline Family Environment & 16.674 & 1 & 16.674 & .729 & Not Significant \\
\hline $\begin{array}{l}\text { Self-Esteem * Family } \\
\text { Environment }\end{array}$ & .007 & 1 & .007 & .000 & Not Significant \\
\hline Error & 3203.417 & 140 & 22.882 & & \\
\hline
\end{tabular}

The above table shows that the main effect of Self-Esteem and Family Environment on Extrasensory Perception is not significant. And the F ratio of double interaction effects of Self-Esteem and Family Environment on the dimension of Extrasensory Perception is also not significant on the same dimension.

Table 6: Summary Table of ANOVA for Main and Interaction Effect of Variables of Self-Esteem and Family Environment on the Dimension of Existential Enquiry

\begin{tabular}{|l|r|r|r|r|l|}
\hline Source & $\begin{array}{l}\text { Type III Sum } \\
\text { of Squares }\end{array}$ & Df & $\begin{array}{l}\text { Mean } \\
\text { Squares }\end{array}$ & F & $\begin{array}{l}\text { Level of } \\
\text { Significance }\end{array}$ \\
\hline Self-Esteem & 5.444 & 1 & 5.444 & .234 & Not Significant \\
\hline Family Environment & 30.250 & 1 & 30.250 & 1.303 & Not Significant \\
\hline $\begin{array}{l}\text { Self-Esteem * Family } \\
\text { Environment }\end{array}$ & 4.694 & 1 & 4.694 & .202 & Not Significant \\
\hline Error & 3250.500 & 140 & 23.218 & & \\
\hline
\end{tabular}

This above table reveals that the main effects of Self-Esteem and Family Environment and also the double interaction of Self-Esteem and Family Environment on the dimension of Existential Enquiry are not significant.

Thus, the first hypothesis that there will be no significant differences in the mean scores of Low and High groups of Self-Esteem of Pre Service Teachers Secondary Stage on dimensions of Spiritual Intelligence is accepted.

The second hypothesis that there will be no significant differences in the mean scores of Non Congenial and Congenial Family Environment groups 

Intelligence is partially accepted for Expansion of Self, Extrasensory Perception and Existential Enquiry and is rejected on the dimensions of Transcendence and Interconnectedness.

The third hypothesis that there will be no significant two way interaction effects between Self-Esteem and Family Environment on dimensions of Spiritual Intelligence of Pre Service Teachers Secondary Stage is accepted.

\section{FINDINGS}

- The Low and High Self-Esteem groups exhibit no significant differences on the variables of Transcendence, Interconnectedness, Expansion of Self, Extrasensory Perception and Existential Enquiry.

- The Congenial and Non Congenial Family Environment groups exhibit significant differences on the variables of Transcendence and Interconnectedness and in favour of Congenial Family Environment group, whereas no significant difference is observed on the variables of Expansion of Self, Extrasensory Perception and Existential Enquiry.

- There are no significant interaction effects of Self-Esteem and Family Environment on all the dimensions of Spiritual Intelligence.

\section{REFERENCES}

Bhatia H, \& Chadha, N. K. (1993), 'Family Environment Scale', Lucknow: Ankur Psychological Agency. Blascovich, J. \& Tomaka, S. (1991), Measures of self-esteem. In Robinson JP, Shaver PR, Wuightsman (Eds.). Measures of personality and social psychological attitudes, San Diego, CA1. Academic Press.

Coopersmith, S. (1975), ' Self-Esteem Inventory’, Palo Alto, Psychologists Press, pp. 95-132.

Freud, S. (1953), 'A General Introduction to Psychoanalysis', New York: Washington Square Press.

Kelley, T. L. (1939), ' The selection of upper and lower groups for the validation of test items', Journal of Educational Psychology, 30, pp.17-24.

Rosenberg, M. (1965), 'Society and the adolescent self-image', Princeton, NJ: Princeton University Press. http://dx.doi.org/10.1126/science.148.3671.804

Sharma, H. and Khurana, V. (2010), 'Spiritual Intelligence Scale’, Ph.D. thesis submitted to Punjab University, Chandigarh.

Sisk, D. and Torrance P. (2001), 'Spiritual Intelligence Developing Higher Consciousness', Creative Education Foundation Press, New York.

Wolman, R.N. (2003), 'Thinking with your soul: Spiritual Intelligence and why it matters. Available from < URL: http://www. Barnessndnoble.com>.

Keerti Vibha is Assistant Professor in SRM College of Education, Raipur Rani, Dist. Panchkula. 